DOI: $10.17951 / \operatorname{lrp} .2018 .37 .2 .11-19$

\author{
NADiYa Ashytok \\ Drohobych Ivan Franko State Pedagogical University \\ ORCID: https://orcid.org/0000-0001-7447-5840
}

\title{
AXIOLOGICAL APPROACH AS A METHODOLOGICAL BASIS OF PEDAGOGY AND EDUCATIONAL PRACTICE IMPROVEMENT
}

\begin{abstract}
Axiological dimension of educational practice has always been topical, but in the times of political, social and economic crisis in Ukraine, in the times of the depreciation of cultural traditions and search for values, shifting of axiological issues towards the centre of scientific reflection and teaching practice is taking place. This is due to many reasons. Decisive among them are the global trend in the change of the basic paradigm of education, its shift from a technocratic to humanitarian one, philosophical rethinking of value and ideological principles of educational practices, as well as of value and ideological content of the educational process; world trends of globalization with inherent intensive migration. Search for axiological bases updates harmonization of national values and values common to mankind in the education system. Understanding the causes of modern education axiologization makes it possible to determine the principal problems that need attention from the part of philosophical and pedagogical reflection, and to promote the reform of the education system taking into account the current requirements of social and personal development in their interconnection.

Scientific knowledge, including pedagogical one, is carried out not only due to the desire to understand the truth, but also for the purpose of the implementation of social issues. Axiological approach provides the link between the educational practices and the knowledge of educational phenomena. For the time being, the idea of values approach is being associated with the implementing of humanistic education paradigm into practice, in the framework of which the main value is a human being.
\end{abstract}

Keywords: axiological approach, education, humanistic educational paradigm, education axiologization

Political, social and economic turmoil in the Ukrainian society has dramatically changed its social and cultural life, has impacted on living standards and has reflected the devaluation of spiritual values. In these conditions, there arises an 
acute need for the education of the younger generation based on human treatment of a person not only to himself/herself but also to other people, to the society and nature. In such a situation there becomes actual the improvement of the efficiency of education as a system that aims on a par with other social institutions to ensure the implementation of axiological (values) function, the essence of which is the introduction of ideological, political, legal, moral, aesthetic and artistic values, as well as humanistic views and beliefs in everyday life and professional activities to the process of education of the youth. The axiological approach in this context becomes particularly important, because on its basis education is considered as the formation process of the system of socially significant values, which are the general guidelines for the younger generation in the process of solving their complex and controversial issues of today.

Axiological nature of education has recently been studied in the scientific literature. Some researchers (V.I. Andreev, Ye.V. Bondarevska, S.V. Kulnevych, V.A. Slastenin, M.N. Chepil and others) consider this approach to be a methodological basis of educational practice, because thanks to it the kind of activity mentioned above gets value orientation (Andreev 2000; Bondarevska 1995a, pp. 23-31; Bondarevska 1995b; Slastenin 1994, pp. 3-8; Kulnevych 2001). Values potential of education has been studied by V.P. Andrushchenko, S.K. Buldakov, B.S. Hershunskyy, I.A. Ziaziun, A.I. Kavalerov, S.B. Krymskyy, V.V. Kumarin, V.S. Lutay, I.A. Radionova, V.M. Rozin, H.G. Tkhahapsoyev, V.I. Shynkaruk and others. Exploring this potential, researchers differentiate between values and values orientation concepts. Some of them - M.V. Demin, A.M. Korshunov, V. Kriukov, V.L. Osovskyy, E.A. Podolska and others - consider value as an objective property of the things intrinsic to it. According to O.M. Bakuradze, A.G. Zdravomyslova, I.S. Narskyy, and Ya.A. Rozin, value is a general understanding of the good sought by a person; value is an ideal and purpose of his/her activities. There is also a view according to which the value is of a subjective and objective nature. Proponents of this view - M.M. Pidlisny and V.I. Shubin - presume the simultaneous existence of both objective and subjective values and attribute this to the problem of absolute and relative values (Pidlisny 2005, pp. 52-53). In their opinion, there are values that are of "objective nature, independent of a direct awareness of a personality". These "higher absolute values" (respect for a human being, patriotism, honesty, etc.) have the status of "eternal" ones. Besides them there are values while comprehending which we "proceed from the category of relevance to the needs and interests of an individual", values, presuming meeting the needs of a particular person. Researchers associate the search for axiological foundations of modern educational paradigms, first of all, with the preservation of "eternal" values that actualizes in an educational sphere the tradition of absolute values philosophy that 
is represented in such philosophical concepts as "the transcendental pragmatics" by K.-O. Apel, "the universal pragmatics" by J. Habermas, "the theory of justice" by J. Rawls, "the theory of enlightened reason" by M. Nussbaum and others. It is clear that education at all times, especially during the political, social and economic crisis must meet the spirit of the times and be directed not only to master new values, but also to preserve the "eternal" ones.

Although there is a great number of works on studying of axiological foundations of education, axiological approach has not been considered sufficiently in the scientific literature. Therefore, it is necessary to study it in detail that explains the choice of the theme of our research.

\section{AXIOLOGICAL APPROACH AS A METHODOLOGICAL BASIS OF PEDAGOGY DEVELOPMENT}

Axiological dimensions of education and upbringing find themselves in the focus of scientists' attention in connection with the search for ways to improve pedagogical practice, aimed at the formation of values in the context of social and personal development in their interconnection due to the ability of values to be an integrated basis for a particular individual and for the society. Values that can be defined as generally accepted beliefs are specified in different contexts. For a human being values are the highest criterion for orientation in the world and the basis of its formation as an individual. The value for a human being is that what defines the purpose of their activities and creates their individuality. Values perform regulatory functions in the social environment. These functions play a crucial role in the life of an individual as a system of values is the foundation of their existence, because practical activities become valuable only in the society, and it is in the society a person is able to live as a human being (Dashutin, Mykhalchenko 2001, p. 201).

One of the social fields within which the formation of values takes place is education. The education system provides transmission of values from one generation to another, promotes the formation of an individual in terms of values. Axiological dimension of pedagogical practice has always been topical, but in periods of depreciation of cultural traditions and of the search for values, as it is happening nowadays, shifting of axiological issues towards the centre of scientific reflection and teaching practice, is due to many reasons. Among the reasons there are such determinative ones as: the global trend of the alternation of the basic paradigm of education, its shift from a technocratic and instrumental to humanitarian and personal one. That requires the development of new fundamental pedagogical 
ideas, rethinking of value and philosophical principles of educational practices as well as value and ideological content of the educational process; world trends of globalization with inherent intense migration processes that are the basis of the emergence of multicultural societies with many values. Search for axiological bases actualizes harmonization of national values and values common to mankind in the education system; establishing intercultural dialogue by means of educational facilities; formation and development of modern education on the principles of multiculturalism. In our time, not only upgrading of the quality and content of education is important, but also its comprehensive democratization and humanization, education reforming not only in terms of the reorganization of its form, but also in terms of upgrading world outlook and values basis of all pedagogical practice. In addition, entry of the national education to the integrated world culture raises the question of preserving the traditional axiological foundations of national education (Andrushchenko, Predborska 2009).

Understanding the causes of modern education axiologization makes it possible to describe the problems requiring attention from the part of philosophical and pedagogical reflection, and promote the reform of the education system taking into account current requirements of social and personal development in their interconnection. Basic concepts of axiological problems are based on general theoretical and methodological approaches developed in the axiology as the philosophical theory of values (Leontiev 1996, pp. 4-36). Therefore, the concepts that examine the nature of values, a combination of objective and subjective in them, mechanisms of their emergence and functioning, exist within paradigmatic concepts as a basis. Among the latter there can be defined such as naturalistic psychology (J. Perry, J. Dewey, R. Lewis); axiological transcendentalism of the Baden School of neo-Kantianism (V. Windelband, H. Rickert); personalistic ontologism (M. Scheler, E. Hartmann); cultural and historical relativism (W. Dilthey, O. Spengler, P. Sorokin) and sociology (M. Weber), etc. In an axiological aspect paradigm concepts (depending on the way the ideal of education and means of its implementation are seen in them) can be combined into groups that can be designated as "value-conservative" (T. Brammeld, K. Rogers, E. Kelley); "valueemancipatory" (emancipatory pedagogy of critical theory of the Frankfurt school); "value-communicative" (K.-O. Apel, O. Bolnov, J. Habermas), etc. In particular, for values and communication paradigmatic concepts the ideal of education is a personality who is able to form effective relationships with other people. Education in this context is seen as a communicative process between individuals.

Organization of educational practice is interpreted by the proponents of a philosophy of the curriculum (J. Barnett, G. Brudie, J. Bruner, L. Rath, B. Smith, P. Phenix, etc.). In their view, value-oriented curriculum is related to the attempts 
to implement humanization and aestheticization of the educational process, to combine learning and education by determining the order and hierarchy of assimilation of disciplinary knowledge and understanding of learning as a process that educates and develops a personality. Within this philosophy, L. Rath, referring to the problem of formation of value consciousness, offers subject-object approach to ensure the integration of knowledge based on the assimilation of values. Analyzing this researcher's concept, I.A. Radionova singles out such approaches to the implementation of the values integration of educational knowledge as: 1) the practice of values instilling that are established either by human community (by legitimizing values through human rights) or are transcendentally justified (that does not exclude the reference to authorities of the state, nation, teachers, parents, etc.); 2) moral development according to a teacher's program; 3) contextual and functional analysis, which provides for inspection and analytical study of those situations where values are an active principle; 4) enlightenment as a qualitatively new stage of a child's spirituality, based on the synthesis of the teacher's teaching and educational work and the pupil's self-development; 5) training should be carried out according to certain values orientations and provide for a synthesis of theoretical knowledge and practical action (Radionova 2001, pp. 186-191).

Certainly, these views about axiological dimension of education do not claim to the status of the only possible ones. Furthermore, one can observe some of their convergence through productive ideas that are available in them. Such convergence is especially characteristic to the national philosophy of education in the development of axiological issues that have significantly become more active in recent years and have been carried out by V.P. Andrushchenko, S.F. Klepko, M.D. Kultayeva, V.O. Ogneviuk, I.M. Predborska, I.O. Radionova, N.O. Tkachova and others.

\section{AXIOLOGIZATION OF EDUCATIONAL PRACTICE}

The formation of axiological approach to understanding educational phenomena has contributed to solving problems of overcoming the crisis of values scope and its development. Application of this approach is associated with the idea of humanizing education that has philosophical and anthropological, as well as social and political significance. Scientific knowledge, including pedagogical one, is carried out not only in order to understand the truth, but also for the purpose of social issues implementation. Axiological approach provides the link between educational practices and knowledge of educational phenomena. This approach involves, on the one hand, the study of phenomena in terms of the possibilities inherent in them to meet the needs of people (including educational ones), and 
on the other hand - solving the task of humanizing the society. The meaning of axiological approach can be disclosed through the system of axiological principles of education activity. Among these principles are such as equality of all views within a single humanistic system of values (while maintaining the diversity of their cultural and ethnic peculiarities); equipollence of tradition and creativity, recognizing the need to study and use of the past, the possibility of understanding the present and planning for the future on the basis of "eternal" values; existential equality of people, social and cultural pragmatism instead of discussions about the basis of values; dialogue instead of indifference or rejection.

For the time being, the idea of values approach is being associated with the implementing of humanistic education paradigm into the practice, in the framework of which the main value is a human being. For a long time, the country's dominant values and target purpose of the system of education was, first and foremost, to meet the state requirements of labour resources. This values and target purpose promoted the formation of a technocratic educational paradigm. Important valuable guidelines of this paradigm were pupils and students' knowledge and skills. It was believed that preparation for employment, professional qualifications of future employees, their work productivity, growth in gross domestic product as the key to social and economic development depended on these parameters. In this approach, the interests of the state were in the first place in the hierarchy of education values. Nowadays, there is a need to formulate such values and target aims of educational policy that would direct educational activities not only towards the interests of economy, business, state, but also towards the interests of a person.

Methodology and practice of analysis of modern pedagogical paradigms that stress the role of axiological (values) factors is being implemented in our time in the "National Doctrine of Education Development" and in laws of Ukraine "On Education". In particular, "The National Doctrine of Education Development in the $21^{\text {st }}$ Century" refers to the need for continuous updating of educational content and organization of educational process in accordance with democratic values, education of the generation of people able to create and develop the values of national culture and civil society. One of the priorities of the state policy in the development of education is the formation of national and universal values. The document accentuates that education aimed at the formation of national values at the same time promotes mastering wealth of world culture, respect for the peoples of the world ("The National Doctrine of Education Development in the $21^{\text {st }}$ Century") by the younger generation. The Law of Ukraine "On Education" refers to the fact that the goal of education is the comprehensive development of an individual as a personality and the biggest value of the society, development of his/her talents, mental and physical abilities, training of high moral qualities, 
formation of citizens able to make a deliberate choice. Underlying principles of education in Ukraine are equality of conditions of each person for the complete realization of his/her abilities, talent, comprehensive development; humanism, democracy, priority of general human cultural wealth, etc. This document states that pedagogical and scientific-pedagogical employees are obliged by instructing and personal example to strengthen the respect to the principles of the common to all mankind moral: truth, justice, devotion, patriotism, humanism, kindness, tolerance, diligence, reasonableness and other virtues; to train children and young people to respect parents, women, elderly people, national traditions and customs, national, historical and cultural values of Ukraine, its government and social system, careful attitude to historical, cultural and natural environment of the country, etc. (Law of Ukraine "On Education").

As one can see, not profit, but a person, his/her formation and development, interests and needs, desires and search for meaning in life should be in the focus of the educational strategy of the modern state and, respectively, of humanistic education paradigm. Certainly, this does not mean that such a task of education as helping a young person in the process of mastering the amount of knowledge, skills and abilities can be removed. There is only a shift of emphasis. If previously the type of value orientations could be described as a technocratic one, focused on economic efficiency and maximum use of education in the interest of the society, a humanistic type of values orientations is aimed at the interests of each person. In consequence of changes from a technocratic paradigm to a humanistic one, priority worldview values of education become such as values of humanity, human and personal dignity, social initiative and creativity, democracy, patriotism, national consciousness.

Interest in axiological problems of modern education is explained by the fact that the crucial state of the Ukrainian society in the early $21^{\text {st }}$ century gives rise to the formation of new meanings and values in life. The process of change of value orientations in this period shows that the society with all its contradictions, uncertainty, social discomfort, spirituality deficit, crises of various kinds shows the tendency of search for humanization that gives the society the opportunity not only to "survive" but also to improve all the spheres of life, including education. It is not enough to proclaim devotion to humanistic guidelines to acquire new quality by the system of education that would meet the needs of the time. It is necessary that on the basis of priority values recognized in our time, axiologization of education and educational practices that would ensure the unity of the content and the form of educational activities occurred. System combining the theoretical reflection in the writings of academics and practical implementation of new value orientations can turn these abstract values to efficient regulators of functioning and development of educational activities. 


\title{
REFERENCES
}

Андреев, В.И., 2000, Педагогика: Учебный курс для творческого саморазвития. Казань: Центр инновационных технологий.

Андрущенко, В., Передборська, I. (ред.), 2009, Філособія освіти: Навчальний посібник. Київ: НПУ імені М.П. Драгоманова.

Бондаревская, Е.В., 1995а, Ценностные основания личностно-ориентированного воспитания. «Педагогика», № 4, рр. 29-36.

Бондаревская, Е.В. (ред.), 1995b, Образование в поисках человеческих смыслов. Ростов-на-Дону: РГПУ.

Дашутін, Г.П., Михальченко, М.I., 2001, Украӥнський експеримент на терезах гуманізму. Київ: Парлам.

Закон України «Про освіту», vnz.org.ua/zakonodavstvo/110-zakon-ukrayiny-proosvitu [access: 04.02.2017].

Кульневич, С.В., 2001, Педагогика тичности от кониепиий до технологий. Ростов-на-Дону: Творческий центр «Учитель».

Леонтьев, А.Д., 1996, Ценность как междисииплинарное понятие: Oпьт многомерной реконструкии. «Вопросы философии», № 4, pp. 15-26.

Національна доктрина розвитку освіти Украӥни у XXI столітmі, file://С:/ Documents\%Downloads/natsionalna\%20doktryna.pdf [access: 10.02.2017].

Підлісний, М.М., 2005, Цінності та буття особистості. Днепропетровск: ДДФА. Радіонова, I.О., 2001, Соціокультурне обьрунтування навчального досвіду: досвід американської традищіі. Висник Харьковского национального университета имени В.Н. Каразина, «Філософські перипетії», № 509.

Сластенин, В.А., 1994, Гуманистическая парадигма педагогического образования. «Магистр», № 6.

\section{PODEJŚCIE AKSJOLOGICZNE JAKO METODOLOGICZNA PODSTAWA ROZWOJU PEDAGOGIKI I DOSKONALENIA PRAKTYKI EDUKACYJNEJ}

\begin{abstract}
Abstrakt: Wymiar aksjologiczny praktyki edukacyjnej od zawsze jest aktualny. W okresie społecznego i gospodarczo-politycznego kryzysu na Ukrainie, oraz zaniechania kulturalnych tradycji i poszukiwania wzorców, daje się zauważyć przemieszczenie problematyki aksjologicznej do centrum refleksji naukowej i praktyki pedagogicznej. Jest to spowodowane wieloma czynnikami, do których należą m.in.: ogólnoświatowa tendencja zmiany podstawowego paradygmatu edukacji, ukierunkowanie jej z technokratycznej na humanistyczną, przemyślenie światopoglądowych zasad praktyki oraz światowe tendencje globalizacji z właściwą jej intensyfikacją procesów migracyjnych. Poszukiwanie aksjologicznych podstaw aktualizuje
\end{abstract}


koordynację ogólnoludzkich i narodowych wartości w systemie edukacji. Uświadomienie sobie przyczyn „aksjologizacji” współczesnej edukacji umożliwia określenie problemów węzłowych, które potrzebują filozoficzno-pedagogicznej refleksji, oraz sprzyja przeprowadzeniu reform w systemie edukacyjnym wraz z uwzględnieniem nowoczesnych wymagań społecznego i osobowościowego rozwoju w ich interakcji.

Wiedza naukowa, w tym pedagogiczna, jest realizowana przez dążenie do tego, żeby ogarnąć prawdę, oraz w celu realizacji potrzeb społecznych. Aksjologiczne podejście zapewnia więź między praktyką edukacyjną a poznawaniem zjawisk pedagogicznych. Obecnie ideę aksjologicznego podejścia kojarzy się z wcieleniem w praktykę humanistycznego paradygmatu edukacji, w ramach którego główną wartością jest człowiek.

Słowa kluczowe: podejście aksjologiczne, edukacja, humanistyczny paradygmat edukacyjny, aksjologizacja edukacji 